DEMOGRAPHIC RESEARCH

VOLUME 33, ARTICLE 30, PAGES 871-908 PUBLISHED 27 OCTOBER 2015

http://www.demographic-research.org/Volumes/Vol33/30/

DOI:10.4054/DemRes.2015.33.30

Research Article

Socio-economic determinants of divorce in

Lithuania:

Evidence from register-based census-linked data

Ausra Maslauskaite

Aiva Jasilioniene

Domantas Jasilionis

Vlada Stankuniene

Vladimir M. Shkolnikov

(C) 2015 Ausra Maslauskaite et al.

This open-access work is published under the terms of the Creative Commons Attribution NonCommercial License 2.0 Germany, which permits use, reproduction \& distribution in any medium for non-commercial purposes, provided the original author(s) and source are given credit.

See http:// creativecommons.org/licenses/by-nc/2.0/de/ 


\section{Table of Contents}

1 Introduction $\quad 872$

$2 \quad$ Background and research questions 873

2.1 Theoretical framework 873

2.2 Lithuanian context 876

$\begin{array}{lll}2.3 & \text { Research questions } & 877\end{array}$

$3 \quad$ Data and methods $\quad 878$

$4 \quad$ Results $\quad 882$

5 Discussion $\quad 887$

6 Acknowledgements $\quad 891$

$\begin{array}{ll}\text { References } & 892\end{array}$

$\begin{array}{ll}\text { Appendices } & 898\end{array}$ 


\title{
Socio-economic determinants of divorce in Lithuania: Evidence from register-based census-linked data
}

\author{
Ausra Maslauskaite ${ }^{1}$ \\ Aiva Jasilioniene ${ }^{2}$ \\ Domantas Jasilionis ${ }^{3}$ \\ Vlada Stankuniene ${ }^{4}$ \\ Vladimir M. Shkolnikov ${ }^{5}$
}

\begin{abstract}
BACKGROUND

Most existing evidence on the socio-economic predictors of divorce in developed countries comes from the USA and from Western and Northern Europe. This study contributes to the scarce literature about socio-economic determinants of divorce in Central and Eastern Europe by examining the case of Lithuania.
\end{abstract}

\section{OBJECTIVE}

The study explores how the levels of educational attainment and economic activity, as well as the interactions of these two variables, influence the risk of first divorce both in the entire population of Lithuania and in its urban and rural sub-populations.

\section{METHODS}

The study uses a census-linked dataset connecting all records from the 2001 census and all first divorce records between the census and December 2003. The impact of education and employment status on the risk of divorce was estimated by applying Poisson regression models.

\section{RESULTS}

Lower education is related to elevated risks of divorce only in large cities: in rural areas the relationship is inverted. For both urban and rural males, being out of the labor

\footnotetext{
${ }^{1}$ Lithuanian Social Research Centre, Vilnius, Lithuania.

${ }^{2}$ Max Planck Institute for Demographic Research, Rostock, Germany.

${ }^{3}$ Corresponding author. Lithuanian Social Research Centre, Vilnius, Lithuania. Max Planck Institute for Demographic Research, Rostock, Germany. E-Mail: jasilionis@demogr.mpg.de.

${ }^{4}$ Lithuanian Social Research Centre, Vilnius, Lithuania.

${ }^{5}$ Max Planck Institute for Demographic Research, Rostock, Germany. New Economic School, Moscow, Russia.
} 
market destabilizes marriage and significantly increases the risk of marital disruption. This pattern was also found for males residing in large cities, regardless of their education. As expected, a lower divorce risk is observed among both urban and rural housewives and other inactive urban females. Unemployment and disability-related inactivity is associated with higher divorce probabilities among rural females.

\section{CONCLUSION}

The study finds evidence of individual socio-economic recourses having substantial differentiating effects on first divorce risk in Lithuania. The direction and size of these effects vary notably by sex and place of residence. This suggests that divorce determinants are complex in post-transitional societies in the region.

\section{Introduction}

The high divorce rates common in many industrial societies have generated a substantial body of research aimed at identifying determinants of marital instability. The socio-economic predictors of divorce have been widely examined in the USA and Western and Northern Europe (Amato and James 2010; Lyngstad and Jalovaara 2010) but to a lesser extent in Central and Eastern Europe (Bukodi and Róbert 2003; Muszynska 2008; Liefbroer and Dourleijn 2006; Härkönen and Dronkers 2006). The scientific literature proves a clear positive link between men's higher socio-economic resources and marital stability, while the effect of women's resources is highly inconsistent. This highlights the mediating role of various contextual factors with respect to divorce, such as gender attitudes, gendered division of labor, and welfare state policies.

In this paper we examine the socio-economic determinants of divorce in Lithuania, a country which, in the 1990s, took to the path of neoliberal capitalism "in a rather radical and uncompromising fashion” (Bohle and Gerskovits 2007: 445). Lithuania also belongs to a distinct cluster of eight Central and Eastern European post-communist countries that joined the EU in 2004. Although Lithuania experienced an economic boom during the first half of the 2000s, this progress was accompanied by an increase in inequality, regional disparities, and failures in social support policies (Bohle and Greskovits 2007). This study explores educational and employment status differentials in divorce risk for women and men in the total population of Lithuania as well as in the urban and rural sub-populations, to take into account the specific urban-rural contextual settings of family life.

Our study contributes to the literature on divorce determinants in several ways. First, it examines the socio-economic gradients of first divorce risks, assuming that 
diversity in socio-economic gradients suggests changes in societal constraints on divorce in the total population and the distinct urban and rural sub-populations (Goode 1962). Examining more closely the differentiation of socio-economic gradients of divorce within the various societal groups, we expand knowledge on the process of the reversal of the social determinants of divorce. Second, the study looks at the effect of socio-economic recourses on divorce risk in the specific context of the transitional postcommunist economic and welfare state. Previous research has found significant variations in the effect of socio-economic recourses on marital stability in different welfare state types of advanced industrial societies (Blossfeld and Müller 2002; Cook et al. 2013). Therefore, by bringing a post-communist country into perspective, we not only enrich the existing empirical evidence but also pose significant theoretical questions about the interaction of various micro- and macro-level determinants of divorce. Third, this study is the first to utilize a unique census-linked dataset covering the entire population, which allows us to estimate the effects of both one-dimensional socio-economic variables and the interactions between education, economic activity status, and urban-rural place of residence. To date, similar datasets based on linkages between censuses and divorce records from population registers have been used for divorce research in only a few, primarily Nordic countries in Europe, and in none of the Central and Eastern European countries.

\section{Background and research questions}

\subsection{Theoretical framework}

Theory suggests that social determinants of divorce are changing over time: this process is gradual and depends on the level of modernization in a society. William J. Goode (1962; 1993) predicted a higher concentration of divorce risk in more privileged groups of society in the early stages of modernization when divorce is still a selective behavior, and a reversal of the divorce risk distribution by social class when divorce becomes normative behavior in more advanced modern societies. At the initial stages of divorce diffusion, social, economic, and legal constraints on divorce are higher, making divorce more accessible to socio-economically advantageous groups. Advancement in modernization decreases social and economic constraints on divorce and makes divorce behavior non-selective: consequently the social class gradient of divorce changes from positive to negative. On the level of society, the decline of external (particularly social and economic) constraints on divorce is a gradual process: during this transition sections of society are exposed to external constraints that differ in level and composition. Previous studies have proved this change in the social determinants of 
divorce for the USA and several European countries over time, examining the educational gradient of divorce for different marital cohorts of men and women and reporting the completion or the ongoing process of the transition (Hoem 1997; de Graaf and Kalmijn 2006; Härkönen and Dronkers 2006; Matysiak, Styrc, and Vignoli 2014).

Goode (1962) explained the social mechanism of the reversal of the association between social class and marital instability by lower class families accumulating a higher internal family strain. Internal family strain includes greater economic problems, lower marital satisfaction, and lower involvement of the husband in household tasks when the wife is in work (Goode 1962). These disadvantageous effects of lower socioeconomic resources on marital quality are also highlighted in the current discussion. Some point to poorer communication and conflict-solving skills among families with lower socio-economic resources (Amato 1996). Thus, lower socio-economic resources have the accumulative disadvantage of economic problems, hardship, and fewer opportunities to cope with marital relational challenges. When external constraints on divorce decrease, higher internal family strain, to which lower class families are more exposed, converts into marital instability and higher divorce risk.

In addition to social class, gender division plays a significant role in marital instability, and thus Goode's ideas are complemented by gender-based micro-economic approaches to divorce. One of these, the 'flexibility' (Cooke and Gash 2010) or 'role combination' hypothesis (Oppenheimer 1997; Blossfeld and Müller 2002), highlights the positive effect of both spouses being employed on marital stability, and consequently the reduction of internal family strain. In advanced industrial societies where the dual-earner family has gained economic significance and has become normative, the wife's employment has a stabilizing effect on marriage. Dual-earner marriages have higher consumption complementarities and can manage economic and social risks more efficiently (Oppenheimer 1997; Stevenson and Wolfers 2007; Cooke and Gash 2010). Because economic returns from employment are dependent on educational capital, spouses with higher education generate higher returns, consequently lowering internal family strain.

The opposing view is summarized in the 'gender role specialization' hypothesis and suggests a negative effect of wife's employment and higher education on marital stability. According to this view, marital stability is based on the social exchange of the economic resources provided by the husband and the unpaid domestic work accomplished by the wife (Becker, Landes, and Michael 1977; Becker 1981). Women's employment and higher educational capital reduce gender role specialization and consequently increase divorce risk. Gender role specialization could be expected to stabilize marriage in more traditional gender settings where structural employment opportunities correspond to gender role expectations. The opposite could be expected in modern dual-earner contexts, where housewife status increases economic pressure on 
marriage quality, in particular among lower class families. Nonetheless, regardless of the social context, housewife status could constrain exit from an unsatisfying marriage because of lack of market-specific capital and limited economic alternatives outside of the marriage.

Empirical evidence supports both gender-based explanations of the social determinants of divorce. For advanced societies, some studies report the stabilizing effect of women's employment on marriage (Cherlin 1992; Chan and Halpin 2002; Jalovaara 2001, 2003; Lyngstad and Jalovaara 2010; Amato and James 2010), while others report an inverse relationship (Svarer and Verner 2006). For Central and Eastern European countries, Liefbroer and Dourleijn (2006) report that the wife's employment increases the risk of union dissolution in Lithuania and Poland, decreases it in Latvia, and has no effect in the Czech Republic, East Germany, Hungary (also in Bukodi and Róbert 2003), and Slovenia. In a recent study on Poland, Styrc and Matysiak (2012) corroborated the results for only the period after 1989. For Russia the effect of women's employment has not been found statistically significant for the Soviet and the transitional periods (Muszynska 2008).

In regard to education in the USA, most studies suggest a clear negative relationship between educational attainment and marital dissolution for women and men, whereas the gradient varies in Northern, Western, and Southern Europe (Oppenheimer 1997; Amato and James 2010; Lyngstad and Jalovaara 2010; Härkönen 2014; Matysiak, Styrc, and Vignoli 2014). Earlier studies on Central and Eastern European women reported a positive educational gradient of divorce in Poland and a negative educational gradient in Lithuania, while in Estonia, Latvia, and Hungary the relationship was not statistically significant (Härkönen and Dronkers 2006; for Hungary also see Bukodi and Róbert 2003). Unlike the evidence for females, the results for males are much more consistent. Most studies report a higher propensity to divorce for men with lower socio-economic resources (Oppenheimer 1997; Amato and James 2010; Lyngstad and Jalovaara 2010; Styrc and Matysiak 2012; Bukodi and Róbert 2003).

The pronounced variation in the wife's employment and education effect has been explained by a number of mediating factors. On the couple level, some highlight the significance of the distribution of unpaid work in marriage and expectations that spouses have towards the gendered division of work (Cooke 2006; Sigle-Rushton 2010). Perceived unfairness or inequity in division of household labor could increase the likelihood of divorce (Frisco and Williams 2003; Amato and James 2010; Cooke 2004, 2006; Bellani and Esping-Andersen 2011). Researchers also point to a number of mediating macro-level factors: the normative gender setting in the society (Cooke 2006; Cooke and Gash 2010), macro-level gender employment patterns (Hansen 2005; Jalovaara 2001), and social policies supporting the equality of the division of labor in 
the household and the dual-earner family model (Blossfeld and Müller 2002; Cooke et al. 2013).

\subsection{Lithuanian context}

For more than three decades Lithuania has maintained a very high divorce level and currently has one of the highest divorce rates in Europe (Statistics Lithuania 2011; Council of Europe 2006; NIDI 2014). Liberalization of divorce legislation in 1965 caused a long-term increase in divorce rates, contrary to other countries where legal changes caused only short-term spikes (Härkönen 2013). From the middle of the 1970s the divorce rate stabilized at a high level (total divorce rate of around 0.3-0.5 (Council of Europe 2006)) with a few short-term fluctuations. Although divorce rates (CDR) have been higher in urban areas throughout the whole period since1965, in recent years the urban-rural gap has almost closed (Statistics Lithuania 2011).

In Lithuania the dual-earner family model has been a long-standing economic necessity (Aidis 2006; Motiejunaite 2010). Female employment rates were high during Soviet rule (around 80\%-85\%) and have remained at a high level (above 65\%) ever since (Kanopiene 1998; Statistics Lithuania 2012a). A pattern of full-time employment dominates and, as with the other two Baltic countries, Estonia and Latvia, the level of female employment in Lithuania is greater than in most other CEE countries and comes close to that of countries in Northern Europe (Eurostat 2014). The educational level of women in Lithuania is also higher than in many other CEE countries and is close to that in Scandinavia. Moreover, there are significantly more women than men with tertiary education (Eurostat 2014).

Despite the predominance of the dual-earner family model and high female employment and educational attainment rates, Lithuanian society can still be characterized as having a traditional gender culture that is resistant to structural genderrole modernization (Juozeliuniene and Kanopiene 1995; Stankuniene and Maslauskaite 2008). Although there was a shift of normative expectations towards a more egalitarian role for men during the 1990s (Westoff and Higgins 2009), there is still strong support for the male breadwinner model in Lithuania, and this is relatively homogeneous across birth cohorts, genders, and socio-economic groups. However, expectations of female family and employment roles are more controversial, and more cohort and gender diversity is found in this respect (Stankuniene et al. 2003). The slow diffusion of gender egalitarianism in Lithuania is not an exception as far as CEE countries are concerned, and this could be caused by low economic prosperity and material security, which in more advanced societies has enhanced the value shift towards more equality (Inglehart and Noris 2003; Pampel 2011). 
As in other former communist countries, the lives of Lithuanian families in the 1990s and 2000s were deeply affected by the political and economic transformation. Despite some commonalities, there is a great deal of variation among the countries that joined the EU in 2004. Lithuania (together with Estonia and Latvia) is a case of neoliberal capitalism with market radicalism, high inequality, and low social inclusion (Bohle and Greskovits 2007; Norkus 2013). In the first half of the 2000s, which overlaps with the observation time of our study, Lithuania and the other two Baltic countries scored worse than other EU8 countries on income equality, had the lowest income redistribution (similar in magnitude to the UK, Ireland, and Spain), high inequalities in returns from education (Zaidi 2009), and the lowest spending on social protection (Lauristin 2011). The economic transformation significantly increased the regional aspects of inequality, leading to regional polarization and divergence. In Lithuania the rural population comprises about one third of the population (according to the 2001 and 2011 population censuses) and has enormous socio-economic disadvantages, such as worse education, very high unemployment, and high poverty rates (Statistics Lithuania 2012). In general, the regional disparities in CEE are 50\% higher than in the EU15, and the Baltic countries are among the leaders (Monastiriotis 2011).

The role of the welfare state in the amortization of the market is minor in Lithuania, and social benefits, in spite of the welfare state, cannot be classified as liberal. The structure of social policy and the coverage of the population outpace the liberal welfare state, but the benefit levels are low and services underdeveloped (Aidukaite 2009; 2011). Although family policy in Lithuania is relatively generous regarding maternity and parental leave, the availability of childcare services and benefits supporting dual-earner families are low (Aidukaite 2011), and social policies supporting gender equality are underdeveloped (Stankuniene, Baublyte, and Maslauskaite 2013).

\subsection{Research questions}

Based on the theoretical assumptions, previous findings, and contextual country-level characteristics, several research questions can be formulated. First, we expect a positive educational gradient in divorce risk in rural areas and a negative gradient in urban areas for both gender groups. We assume that the post-communist transition resulted in large socio-economic inequalities and regional disparities that produce distinct social contexts with pronounced differences in the external constraints on divorce. As the legal barriers to divorce have been low in Lithuania for a long period, we expect that 
the external social and economic constraints on divorce will be higher in more socioeconomically disadvantageous contexts and lower in more advantaged contexts.

Based on previous findings, we anticipate a gender differentiation in the effect of employment on divorce risk. Thus our second hypothesis states that unemployed men will experience higher divorce risk than employed men, regardless of their living situation. This expectation stems from the assumption that a husband's unemployment has a negative economic outcome on family life that causes higher internal strain, and that the inability to fulfill the male-breadwinner role that prevails across all social contexts in Lithuania results in lower marital quality.

Third, the wife's unemployment will have a stabilizing effect on marriage in more advanced segments of Lithuanian society. Gender role specialization will affect marital stability in a positive way because the economic necessity of a dual earner family is counterbalanced by prevailing traditional gender roles and the lack of institutional support and appropriate policies promoting gender equality at home and at work.

Fourth, women's unemployment will have a de-stabilizing effect in the more socio-economically disadvantageous parts of Lithuanian society. In these contexts women's unemployment will intensify divorce risk because of the very high internal economic family strain and its possible negative effect on marital quality. The economic necessity for women's income will shape marital stability despite this women's role contradicting traditional gender role expectations.

\section{Data and methods}

This study uses a census-linked dataset, unique in this part of Europe, connecting all records from the 2001 Lithuanian Population and Housing Census and the first-divorce records from the Lithuanian population register covering the period between the census date (6 April 2001) and the end of the follow-up (31 December 2003). The dataset was created in two steps. The first step linked individual census records with divorce, death, and emigration records for individuals from the census. The data on dates of death and emigration were needed in order to estimate the precise number of married years of exposure to risk during the period of follow-up. The linkage procedures were implemented using personal identification numbers as unique identifiers (carried out by employees of Statistics Lithuania, who have access to individual-level data). In the second step, individual-level data were transferred into an aggregated multidimensional frequency format that provides aggregated numbers of first divorce and population exposure for every possible combination of available variables. This data structure is particularly suitable for calculating period risk measures such as divorce rates or Poisson regression relative risks. 
The data cover all formally married individuals (first marriages only) between the exact ages 15 and 60 who reported themselves as being married and indicated first marriage dates (95\% of all reported marriages) at the census. Using the population census as a basis, person-years at risk were estimated by adding up the years of married persons (first marriages only) living during the period of observation (between the 2001 census date of 01 April 2001 and 31 December 2003). For individuals who died or emigrated, the exposure time was censored at the date (month and year) of death or emigration. The final dataset includes 41,000 first (legal) divorces and 3.18 million person-years of married years of exposure.

The data were split by the following variables: duration of first marriage, marriage cohort, age at first marriage, sex, number of children (information available for females only), education, ethnicity, economic activity status, and urban-rural residence.

Information on the key independent variables, education and economic activity status of individuals, as well as on the number of children, ethnicity, and urban-rural residence, was obtained from the population census records. The variables of duration of first marriage, marriage cohort, and age at first marriage were constructed using the exact date of marriage from both the census and divorce records and the exact date of birth provided at the census. The education variable consists of three categories: higher education (university and non-university) (ISCED 5-6), secondary (upper secondary) (ISCED 3-4), and lower than secondary (ISCED 0-2). The economic activity status variable differentiates between the economically active and inactive populations. The economically active sub-population is further divided into employed and unemployed, and the economically inactive sub-population is distributed according to the following four categories: disabled, housewives/househusbands, students, and pensioners and others. For more details on these and other control variables used in the analysis (categories, married years of exposure, and number of events), see Table 1. 
Maslauskaite et al.: Socio-economic determinants of divorce in Lithuania

Table 1: Percentage distributions of first divorces, married years at risk (in thousands), and married persons at census by education, economic activity status, and control variables. Lithuanian females and males, 2001-2003

\begin{tabular}{|c|c|c|c|c|c|c|}
\hline & \multicolumn{3}{|c|}{ Females } & \multicolumn{3}{|c|}{ Males } \\
\hline & $\begin{array}{c}\text { First } \\
\text { divorces }\end{array}$ & $\begin{array}{c}\text { Married } \\
\text { years at risk }\end{array}$ & $\begin{array}{l}\text { Married } \\
\text { persons at } \\
\text { census }\end{array}$ & $\begin{array}{c}\text { First } \\
\text { divorces }\end{array}$ & $\begin{array}{c}\text { Married } \\
\text { years at risk }\end{array}$ & $\begin{array}{c}\text { Married } \\
\text { persons at } \\
\text { census }\end{array}$ \\
\hline \multicolumn{7}{|l|}{ Education } \\
\hline Higher & 21.0 & 20.8 & 20.6 & 16.1 & 17.3 & 17.1 \\
\hline Secondary & 67.2 & 69.2 & 68.4 & 67.5 & 68.5 & 67.4 \\
\hline $\begin{array}{l}\text { Lower than } \\
\text { secondary }\end{array}$ & 11.8 & 10.1 & 11.0 & 16.4 & 14.2 & 15.4 \\
\hline \multicolumn{7}{|c|}{ Economic activity status } \\
\hline Active, employed & 69.0 & 67.8 & 66.4 & 69.1 & 74.8 & 74.0 \\
\hline Active, unemployed & 14.2 & 13.3 & 12.9 & 19.6 & 15.2 & 15.3 \\
\hline Inactive, disabled & 2.1 & 4.0 & 4.4 & 2.6 & 4.2 & 4.8 \\
\hline $\begin{array}{l}\text { Inactive, } \\
\text { housewife/househus } \\
\text { band }\end{array}$ & 8.7 & 10.3 & 10.0 & 1.2 & 1.5 & 1.5 \\
\hline Inactive, student & 2.6 & 1.1 & 1.1 & 0.6 & 0.2 & 0.2 \\
\hline Inactive, other & 2.4 & 3.4 & 5.1 & 4.8 & 3.8 & 3.9 \\
\hline Unknown & 1.0 & 0.1 & 0.1 & 2.2 & 0.3 & 0.3 \\
\hline \multicolumn{7}{|c|}{ Duration of marriage (years) } \\
\hline$<1$ & 0.4 & 0.3 & 0.3 & 0.4 & 0.3 & 0.3 \\
\hline $1-1.99$ & 3.6 & 2.2 & 2.2 & 3.8 & 2.3 & 2.3 \\
\hline $2-2.99$ & 5.1 & 2.4 & 2.4 & 5.2 & 2.5 & 2.5 \\
\hline $3-3.99$ & 5.4 & 2.5 & 2.4 & 6.0 & 2.6 & 2.5 \\
\hline $4-4.99$ & 5.4 & 2.5 & 2.4 & 5.7 & 2.6 & 2.5 \\
\hline $5-5.99$ & 4.9 & 2.6 & 2.5 & 5.1 & 2.7 & 2.6 \\
\hline $6-7.99$ & 11.0 & 5.6 & 5.5 & 11.4 & 5.9 & 5.8 \\
\hline $8-9.99$ & 10.1 & 6.1 & 6.0 & 10.3 & 6.4 & 6.3 \\
\hline $10-12.99$ & 15.6 & 11.1 & 10.9 & 15.4 & 11.7 & 11.4 \\
\hline$>13$ & 38.5 & 64.7 & 65.4 & 36.8 & 63.0 & 63.9 \\
\hline \multicolumn{7}{|l|}{ Marriage cohort } \\
\hline Before 1970 & 1.6 & 9.2 & 11.3 & 1.1 & 5.7 & 7.8 \\
\hline 1970 - 1979 & 10.3 & 25.0 & 24.5 & 9.8 & 25.3 & 25.1 \\
\hline 1980-1989 & 31.3 & 34.1 & 33.1 & 30.7 & 35.9 & 34.7 \\
\hline 1990 - 1994 & 26.2 & 16.4 & 16.1 & 26.2 & 17.3 & 16.8 \\
\hline $1995-2001$ & 30.5 & 15.3 & 15.0 & 32.1 & 15.9 & 15.6 \\
\hline
\end{tabular}


Table 1: (Continued)

\begin{tabular}{|c|c|c|c|c|c|c|}
\hline & \multicolumn{3}{|c|}{ Females } & \multicolumn{3}{|c|}{ Males } \\
\hline & $\begin{array}{c}\text { First } \\
\text { divorces }\end{array}$ & $\begin{array}{c}\text { Marriage } \\
\text { years at risk }\end{array}$ & $\begin{array}{c}\text { Married } \\
\text { persons at } \\
\text { census }\end{array}$ & $\begin{array}{c}\text { First } \\
\text { divorces }\end{array}$ & $\begin{array}{c}\text { Marriage } \\
\text { years at risk }\end{array}$ & $\begin{array}{l}\text { Married persons } \\
\text { at census }\end{array}$ \\
\hline \multicolumn{7}{|c|}{ Age at marriage (years) } \\
\hline$<20$ & 26.0 & 18.3 & 18.2 & 8.7 & 5.1 & 5.1 \\
\hline $20-24$ & 56.0 & 60.2 & 59.8 & 60.1 & 57.5 & 56.7 \\
\hline $25-29$ & 13.0 & 16.2 & 16.4 & 23.0 & 28.8 & 29.2 \\
\hline$>30$ & 5.0 & 5.4 & 5.6 & 8.2 & 8.6 & 9.0 \\
\hline \multicolumn{7}{|l|}{ Number of children } \\
\hline No children & 0.1 & 0.1 & 0.1 & - & - & - \\
\hline 1 child & 44.2 & 27.9 & 27.8 & - & - & - \\
\hline 2 children & 34.7 & 49.6 & 49.3 & - & - & - \\
\hline 3 or more children & 8.3 & 16.3 & 16.4 & - & - & - \\
\hline Unknown & 12.7 & 6.2 & 6.3 & - & - & - \\
\hline \multicolumn{7}{|l|}{ Ethnicity } \\
\hline Lithuanian & 84.4 & 83.2 & 83.3 & 83.9 & 83.1 & 83.1 \\
\hline Russian & 6.8 & 6.1 & 6.1 & 7.0 & 6.3 & 6.3 \\
\hline Polish & 5.2 & 7.6 & 7.5 & 4.7 & 7.1 & 7.1 \\
\hline Other & 2.8 & 3.1 & 3.0 & 3.1 & 3.5 & 3.5 \\
\hline Unknown & 0.7 & 0.1 & 0.1 & 1.3 & 0.1 & 0.1 \\
\hline \multicolumn{7}{|l|}{ Place of residence } \\
\hline Urban - large cities & 48.2 & 39.7 & 39.7 & 50.1 & 38.7 & 38.8 \\
\hline Urban - other & 32.2 & 29.7 & 29.6 & 30.0 & 29.9 & 29.7 \\
\hline Rural & 19.6 & 30.6 & 30.7 & 19.8 & 31.4 & 31.4 \\
\hline \multicolumn{7}{|l|}{ Place of birth } \\
\hline Urban, Lithuania & 58.5 & 41.4 & 40.5 & 57.4 & 41.0 & 41.1 \\
\hline Rural, Lithuania & 34.5 & 51.5 & 52.1 & 34.7 & 51.7 & 51.9 \\
\hline Other country & 6.1 & 6.8 & 7.1 & 6.6 & 7.1 & 6.8 \\
\hline Unknown & 0.9 & 0.3 & 0.2 & 1.4 & 0.2 & 0.3 \\
\hline $\begin{array}{l}\text { TOTAL (in } \\
\text { thousands) }\end{array}$ & $19.8(100)$ & $1440.4(100)$ & $554.0(100)$ & $18.0(100)$ & $1346.3(100)$ & $520.1(100)$ \\
\hline
\end{tabular}

Note: Distributions of married persons at census refers to persons between exact ages 15 and 60 at the moment of census. 
The impact of socio-economic status on the risk of divorce was estimated by applying Poisson regression for count data, with the first divorce as the dependent variable. The model can be defined using the following equation:

$$
D_{j}=E_{j} e^{\beta_{0}+\beta_{1} x_{1, j}+\ldots+\beta_{k} x_{k, j}}=e^{\ln \left(E_{j}\right)+\beta_{0}+\beta_{1} x_{1, j}+\ldots+\beta_{k} x_{k, j}},
$$

where $j$ is a combination of categories of explanatory variables under consideration, $D_{j}$ is the expected number of first divorces, $E_{j}$ is the number of married years of exposure to risk, $x_{1, j}, \ldots, x_{k, j}$ are explanatory variables, and $\beta_{0}, \beta_{1}, \ldots$, and $\beta_{k}$ are effects of independent explanatory variables. For each combination of $j$, the Poisson regression model estimates expected divorce rates expressed as the ratios between the expected number of first divorces $D_{j}$ and the number of married years of exposure $E_{j}$. The main effects of independent explanatory variables are presented as relative first divorce risks (expressed as expected divorce rate ratios between divorce rates in the categories under study and corresponding rates in the reference categories). In addition to the models showing the main effects, models with interaction terms between sex and education, sex and economic activity status, place of residence and education, place of residence and economic activity status, and between education and economic status were estimated. Using Likelihood Ratio tests, these models were compared to the initial main models including all variables but without interaction terms.

\section{Results}

The total first-divorce rates for total population by education and economic activity status are provided in Table 2. This period indicator is calculated as the sum of (firstmarriage) duration-specific ratios between the number of first divorces and the corresponding number of first-marriage years of exposure during the period of observation. Total first-divorce rate refers to the share of marriages that would end in divorce if the divorce risk observed during 2001-2003 remained fixed during the entire marriage. The results confirm a very high overall divorce level in Lithuania that coincides with notable socio-economic gradients in first-divorce rates (Table 2). Females with lower than secondary education and males with secondary and lower than secondary education had substantially higher divorce levels. Although the lowest divorce rates were observed among both housewives and househusbands, the remaining categories of economic activity status showed important gender differences. Interestingly, among males, the second group after househusbands showing notably lower divorce rates is employed males, whereas among females those employed had 
lower divorce rates only if compared to unemployed and disabled females. The highest first-divorce rates were found for unemployed females and male students. Among males, equally striking (above 0.70 ) rates were also found in the unemployed group. Disabled and other inactive males occupied an intermediate position between unemployed and employed males. For females, the second-highest divorce rate was observed in the economically inactive disabled group. Unlike for males, the divorce rate among female students was similar to that of employed females. Other inactive females had the second lowest divorce rate after housewives. Due to very specific distributions of first divorces and the corresponding numbers of first-marriage years of exposure by first-marriage duration, it was not possible to calculate total divorce rates for females and males with unknown economic activity status.

Table 2: $\quad$ Total first divorce rates for total population by education and economic activity status. Lithuanian females and males, 2001-2003

\begin{tabular}{lll}
\hline & Females & Males \\
\hline Education & & \\
Higher & 0.51 & 0.44 \\
Secondary & 0.49 & 0.62 \\
Lower than secondary & 0.58 & 0.57 \\
& & \\
Economic activity status & & \\
Active, employed & 0.51 & 0.42 \\
Active, unemployed & 0.57 & 0.72 \\
Inactive, disabled & 0.56 & 0.55 \\
Inactive, housewife / househusband & 0.32 & 0.39 \\
Inactive, student & 0.51 & 0.75 \\
Inactive, other & 0.44 & 0.58 \\
TOTAL & $\mathbf{0 . 5 0}$ & $\mathbf{0 . 5 0}$ \\
\hline
\end{tabular}

Because the observed differences in the total first-divorce rates by education and economic activity status depend on confounding effects of other socio-demographic characteristics, we applied Poisson regression models controlling for all the available independent explanatory variables. We found that models with interactions between gender and education and gender and economic activity status fit better than the models without interactions. Therefore, our further analysis was based on separate models for females and males. ${ }^{6}$ Although the model with interaction suggests a weaker educational

\footnotetext{
${ }^{6}$ Models without interactions are shown in Appendices 1 and 2. See Appendices 3 and 4 for the interaction estimates and goodness of fit statistics.
} 
divorce gradient for females, the results from the gender-specific models indicate that relative effects of education on divorce risk are similar (Table 3). For both total females and males we found the same direction of inequality, with the least-educated group having moderately higher divorce rates, and those with secondary education having about the same as those with tertiary education. For economic activity status, we found very notable gender differences in the size and even in the direction of the effects. Divorce risks among unemployed, disabled, and other inactive males are very high relative to active, employed males, whereas no such differences are observed for females. Instead, the lowest divorce rates were observed among housewives.

Table 3: Poisson regression of relative first-divorce risks by education and economic activity status, estimated for total female and male subpopulations, Lithuania, 2001-2003

\begin{tabular}{lll}
\hline Education / economic activity status category & Females & Males \\
\hline & & \\
Education & & 1.00 \\
\hline Higher & 1.00 & 1.04 \\
Secondary & 1.01 & 1.27 \\
Lower than secondary & 1.23 & \\
& & \\
Economic activity status & & 1.00 \\
\hline Active, employed & 1.00 & 1.43 \\
Active, unemployed & 1.02 & 1.28 \\
Inactive, disabled & 0.98 & 1.09 \\
Inactive, housewife / househusband & $\mathbf{0 . 7 4}$ & 1.17 \\
Inactive, student & 0.99 & 1.42 \\
Inactive, other & $\mathbf{0 . 8 8}$ & 4.60 \\
Unknown & 4.36 & \\
\hline
\end{tabular}

Note: statistically significant relative risks are marked in bold $(p \leq 0.05)$. Outcomes from models controlling for all variables.

The gender-specific models with interactions between urban-rural place of residence and education, residence, and economic activity status also fit better than the corresponding models without interactions. ${ }^{7}$ As shown in Tables 4 and 5, educational gradients in first-divorce risk are less pronounced in other cities and rural areas than in large cities. The negative association between education and divorce is found only in

\footnotetext{
${ }^{7}$ See Appendices 5 and 6 for interaction estimates and goodness of fit statistics
} 
large cities for both females and males. For males residing in smaller cities ("other urban areas") and rural areas, the educational gradient in first-divorce risk is in the opposite direction: males with secondary and lower than secondary education have lower divorce risks than those with tertiary education. For females, no educational differences are found in other urban areas, and those with secondary education have lower risks than those with higher education in rural areas.

Table 4: $\quad$ Poisson regression of relative first-divorce risks by education and economic activity status estimated for large cities, other urban areas, and rural areas. Lithuania, females, 2001-2003

\begin{tabular}{llll}
\hline $\begin{array}{l}\text { Education / economic } \\
\text { activity status category }\end{array}$ & Large cities & $\begin{array}{l}\text { Other urban } \\
\text { areas }\end{array}$ & Rural areas \\
\hline
\end{tabular}

\section{Education}

\begin{tabular}{llll}
\hline Higher & 1.00 & 1.00 & 1.00 \\
Secondary & 1.07 & 0.94 & 0.85 \\
Lower than secondary & 1.55 & 1.01 & 0.93 \\
\hline
\end{tabular}

Economic activity status

\begin{tabular}{llll}
\hline Active, employed & $\mathbf{1 . 0 0}$ & $\mathbf{1 . 0 0}$ & $\mathbf{1 . 0 0}$ \\
Active, unemployed & $\mathbf{0 . 8 8}$ & 1.04 & $\mathbf{1 . 3 9}$ \\
Inactive, disabled & 0.86 & 1.01 & $\mathbf{1 . 2 5}$ \\
Inactive, housewife & $\mathbf{0 . 6 3}$ & $\mathbf{0 . 8 4}$ & $\mathbf{0 . 8 2}$ \\
Inactive, student & 0.95 & 1.02 & 1.15 \\
Inactive, other & $\mathbf{0 . 8 2}$ & 0.92 & 1.08 \\
Unknown & $\mathbf{4 . 0 7}$ & $\mathbf{2 . 5 6}$ & $\mathbf{4 . 8 5}$ \\
\hline
\end{tabular}

Note: statistically significant relative risks are marked in bold $(p \leq 0.05)$. Outcomes from models controlling for all variables.

Differences by economic activity status also varied across the three urban-rural sub-populations. The positive effect of men's unemployment or disability on divorce risk was greatest in rural areas, smallest in large cities, and in-between these in other urban areas. For women, however, unemployment was negatively associated with divorce in large cities and positively associated with divorce in rural areas. Disabled women were also more likely to divorce in rural areas but not in cities. Housewives had lower divorce risks in all areas, but the largest difference to employed women was in large cities. Househusbands had no higher risk than employed men across areas. Male 
students in rural areas also had very high divorce rates compared to employed men, but being a student did not affect divorce in cities.

Table 5: Poisson regression of relative first-divorce risks by education and economic activity status estimated for large cities, other urban areas, and rural areas. Lithuania, males, 2001-2003

\begin{tabular}{llll}
\hline $\begin{array}{l}\text { Education / economic } \\
\text { activity status category }\end{array}$ & Large cities & Other urban areas & Rural areas \\
\hline & & & \\
Education & & & \\
\hline Higher & 1.00 & 1.00 & 1.00 \\
Secondary & 1.25 & 0.74 & 0.75 \\
Lower than secondary & 1.76 & 0.82 & 0.81 \\
\hline & & & \\
Economic activity status & & & \\
\hline Active, employed & 1.00 & 1.00 & 1.00 \\
Active, unemployed & 1.25 & 1.54 & 1.70 \\
Inactive, disabled & 1.15 & 1.33 & 1.16 \\
Inactive, househusband & 1.08 & 1.19 & 1.85 \\
Inactive, student & 1.18 & 0.93 & 1.90 \\
Inactive, other & 1.16 & 1.48 & 7.99 \\
Unknown & 3.73 & 4.22 & \\
\hline
\end{tabular}

Note: statistically significant relative risks are marked in bold $(p \leq 0.05)$. Outcomes from models controlling for all variables.

The final step of the analysis was to consider the importance of interactions between education and economic activity status. Therefore, for each gender and urbanrural location we tested models by including interaction terms between the two variables. We found that the inclusion of interaction term is meaningful only in large cities. $^{8}$

Figure 1 presents relative first-divorce risks across the combined groups of education and economic activity status in large cities. Employed women at all educational levels are more likely to divorce than housewives and other non-employed women. However, the differences are more pronounced at the highest and lowest education levels. Unemployment was associated with increased divorce risk among males with secondary and higher education but not for men with the lowest education.

\footnotetext{
${ }^{8}$ See Appendices 7 and 8 for estimated interaction coefficients and model fit statistics.
} 
Figure 1: Poisson regression of relative first-divorce risks, economic activity status, estimated for each educational category. Lithuania, females and males, 2001-2003

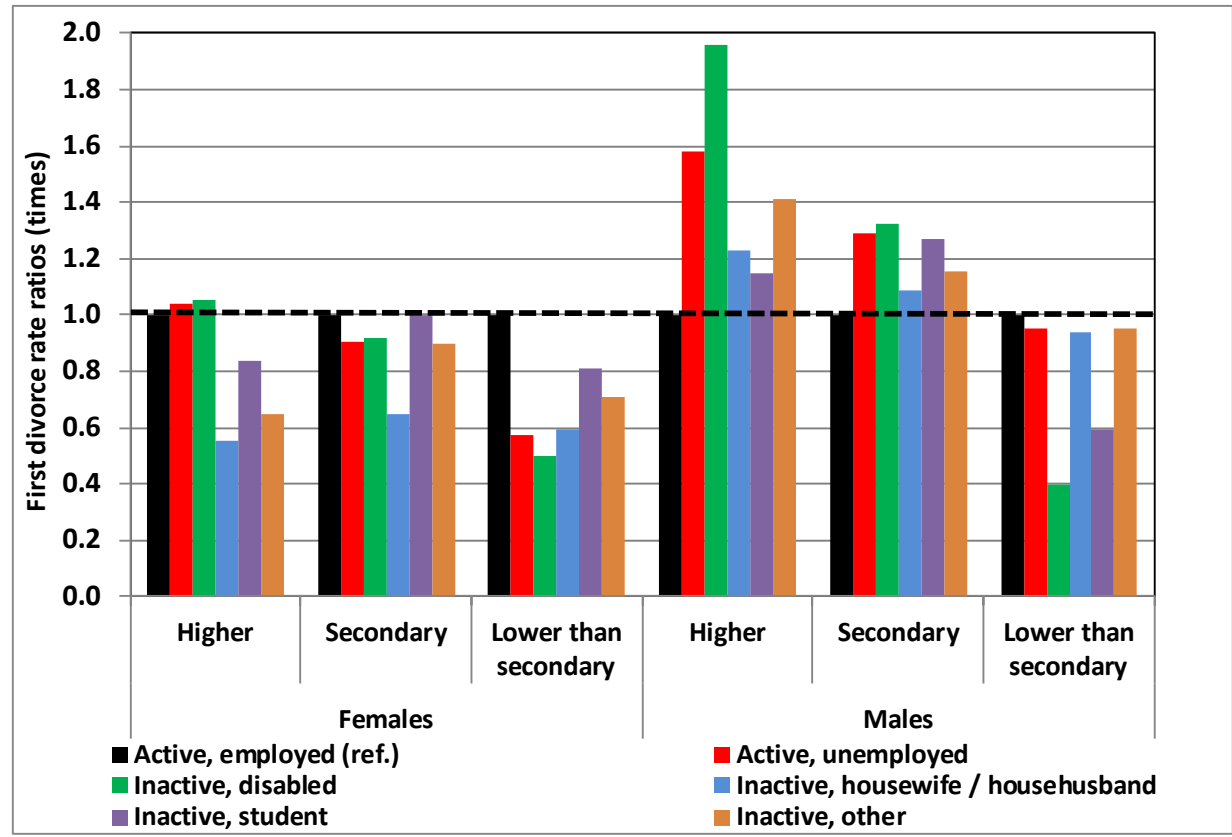

Note: outcomes from models including all control variables.

\section{Discussion}

This study finds evidence of the differentiating effect of individual socio-economic resources, measured by the level of educational attainment and economic activity status, on the risk of first divorce in Lithuania at the beginning of the $21^{\text {st }}$ century. One of the major advantages of the study is that it uses census-linked data covering the entire adult population of Lithuania. Thus all statistical analyses in this study are based on a very large sample size, allowing for statistically robust group-specific estimates of firstdivorce risks. More important, these data also include vulnerable sections of society, such as people in institutions and marginal population groups. This solves the problem of the selection bias that is often present in survey data due to under-representation of these groups. Finally, this particular set of data provides a unique opportunity to also 
study the determinants of first divorce and the pattern of their effects within subpopulations.

This study also has some limitations that should be considered before interpreting the results. One of the most important shortcomings is that the socio-economic variables used in the analysis are time-constant and refer to the date of the census. We partially overcome this disadvantage by creating very broad categories (e.g., three categories for education) and by focusing on a relatively short period of observation (2.5 years). To check the potential impact of changes in socio-economic status on our results, we performed a sensitivity analysis restricting the period of observation to one year. This test returned very similar results and confirmed our findings. Another possible drawback of the data is related to a potential bias in married years at risk due to underestimation of true emigration levels (only official emigration records were used). Using indirect estimates of unregistered (undeclared) emigration by Statistics Lithuania (Statistics Lithuania 2008), we found that this undercount probably has only a very minor effect on divorce rates in Lithuania. In addition, our study is restricted to married people, who generally have much lower migration rates compared to other population groups. Finally, it is also possible that some people may have misreported their actual urban-rural place of residence. However, thanks to systematic cross-checking with population register data by Statistics Lithuania, we believe that there is no substantial misreporting of place of residence that could significantly influence our results.

One of the study's most important findings concerns distinct socio-economic gradients of first divorce in Lithuania, showing notable differences in the magnitude and even direction of these gradients in urban and rural sub-populations. Following Goode's $(1962,1993)$ theory, this suggests the importance of existing specific social constraints (at both macro- and micro-levels) contributing unequally to divorce chances in urban and rural settings. In general, our findings support Goode's ideas on the social class composition of divorce, and its gradual reversal progressing in accordance with the overall modernization of a society.

The study addresses four specific research questions. First, in line with Goode's proposition and existing evidence from other countries, we expected a positive educational gradient in divorce risk in rural areas and a negative educational gradient in urban areas, and homogeneous gender effects in this regard. Our results confirmed that high education has a stabilizing effect on marriage for females and males residing in large cities. At the same time, we found the opposite or statistically insignificant results for urban males and for both males and females in rural settings. These urban-rural variations in divorce risk by education could be explained by the pronounced differences in the socio-economic external constraints on divorce in more-modernized urban and less-advanced rural areas. We could assume that these urban-rural differences in divorce constraints were also reinforced by the post-communist transition that 
brought large regional socio-economic inequalities and disparities and consequently deepened the urban-rural division (Zaidi 2009; Monastriotis 2011). Thus, in a modern urban context, the external socio-economic constraints are lower, because the social acceptance of divorce is high, and the economic opportunities to secure independent living are more favorable due to the general trends of economic transition. In these contextual conditions the divorce risk is concentrated among the lower educational groups, as they experience more internal economic and relational family strain, and consequently dissolve the marriage more often. Findings for highly educated males and females residing in Lithuania's large cities suggest that there is a protective accumulative economic and marital quality effect of higher education on marital stability (Stevenson and Wolfers 2007). Contrary to in more advantageous contexts, in rural areas the educational gradient of divorce is positive because social and economic external constraints on divorce are higher and the opportunities to overcome them are only available to the more privileged groups. People with higher education have a significant advantage when it comes to securing economic well-being in rural areas with very high unemployment rates and intensified poverty risk (Statistics Lithuania 2012), and consequently they are able to exit unsatisfying marriage more easily.

Our second hypothesis stated that unemployed men will experience higher divorce risk, regardless of where they live. This was anticipated by taking into account the intersection of social class and gender divisions in divorce determinants and the context of the prevailing traditional gender culture (where the male is the breadwinner) in Lithuania. In this context, men's unemployment generates a higher internal family strain, associated with economic shortages and lower marital quality caused by the inability to fulfill the male-breadwinner role. Our results that systematically show a striking increase in divorce risk among the unemployed, the economically inactive disabled, and other inactive males confirmed this hypothesis, and are in line with the gender role specialization (Becker 1981) and gender role combination hypotheses (Oppenheimer 1997) that propose a unified view of the relevance of male employment on marital stability. This pattern was remarkably similar in all sub-populations, from large cities to rural areas, which signifies that normative expectations of male roles in Lithuania are generally homogeneous across social classes, generations, and genders (Juozeliuniene and Kanopiene 1995; Stankuniene and Maslauskaite 2008). This hypothesis is further supported by the finding that unemployment and disability are associated with a notably increased divorce risk even among highly educated males residing in large cities.

Our third hypothesis stated that wife's unemployment will have a stabilizing effect on marriage in more advanced areas in Lithuanian society, and was based on the assumption that the economic necessity of the dual-earner family is counterbalanced by the prevailing traditional gender roles and a lack of institutional support and appropriate 
policies promoting gender equality at home and at work. The intensified divorce risk for employed females in large cities supports this hypothesis. Taking the results for males and females together, we found more support for the gender specialization hypothesis than the gender role combination hypothesis in more advanced, modern urban settings. The significant factor at play here is the limited de-familization of care and low institutional support for work-life balance (Stankuniene, Maslauskaite, and Baublyte 2013). For working women, this results in intensified internal family strain: even more so if we consider the dominant full-time female employment pattern (Statistics Lithuania 2012) and the traditional gender expectations towards female family roles. We can also assume that in this context becoming unemployed or dropping out of the labor market will not increase the divorce risk because it creates the opportunity to accept or/and adapt to the status of economic inactivity by fulfilling expectations based on traditional gender roles in the family (Hakim 2003) and avoiding work-family conflict. Indirect support for this argument is provided by the finding of systematically lower risks of divorce for housewives in all of the populations under study. However, it is also possible that the observed result stems from other factors, such as limited economic opportunities for housewives to exit unhappy marriages (Becker 1981).

Fourth, we hypothesized a de-stabilizing effect of women's unemployment in more socio-economically disadvantageous areas in Lithuanian society. The observed higher divorce risk among unemployed rural females may be interpreted using a gender-role combination framework, suggesting the importance of pooled resources in order to survive economic and social risks (Stevens and Wolfers 2007). In the Lithuanian rural context, the loss of a wife's income could lead to extreme poverty for the household, cause accumulation of relational stress in the family, and influence the decision to get a divorce. This may be particularly important given the substantially lower overall levels of income and the high unemployment in rural areas, as well as the high prevalence of other related problems such as alcoholism and family violence against women (ITCD 2014).

Almost all the aforementioned explanations mainly address the direct causal effect of socio-economic status on first divorce. However, the existence of a reverse association between these two variables is also very likely; i.e., divorce could lead to lower socio-economic status. Although in the Lithuanian dataset socio-economic status is fixed at the census baseline (before the occurrence of divorce), there could be other (indirect) forms of reverse causation. For example, Jalovaara (2001) suggests that lower socio-economic resources may point to the weakness of a marriage, related to a lack of interest in accumulating joint resources.

Our study has shed more light on the importance of the socio-economic factors of first divorce in Lithuania and has thus contributed to filling the gap in the knowledge of divorce predictors in this country and in the Central and Eastern European region. Our 
findings point to striking differences in socio-economic determinants of divorce between sub-populations, even in such a small country as Lithuania. Such diversity in determinants and contexts shaping the process of marital dissolution should be taken into account when developing family policies devoted to strengthening marital stability.

Unfortunately, the restrictive nature of the census-linked data provided relatively few individual characteristics, which prevented us from testing a wider range of alternative explanations or examining confounding effects on education and economic activity status more thoroughly. It is possible that some unmeasured factors, such as psychological characteristics or family background, are important contributors to the propensity to dissolve first marriages in Lithuania, and that additional controls for these effects would lead to some changes in the relative risks associated with the two socioeconomic variables. More comprehensive explanatory studies based on more detailed data and advanced methods employing controls for unobserved heterogeneity are required in order to confirm and explain the observed relationships.

\section{Acknowledgements}

We are very grateful to the Associate Editor and two anonymous reviewers for insightful and detailed comments. The authors would like to acknowledge Statistics Lithuania for compiling and providing high quality aggregated census-linked dataset on first divorces in Lithuania. This study was funded by the European Social Fund under the measure VP-1-3.1-ŠMM-07-K "Support to Research Activities of Scientists and Other Researchers" (Global Grant) (the grant No. VP1-3.1-SMM-07-K-02-067). The research was performed by the Lithuanian Social Research Centre in cooperation with the Max Planck Institute for Demographic Research (Germany). 


\section{References}

Aidis, R. (2006). From business ownership to informal Market Traders: the Characteristics of Female Entrepreneurship in Lithuania. In: Welter, F., Smallbone, D., and Isakova, N. (eds.). Enterprising Women in Transitional Economies. Aldershot: Ashgate: 119-143.

Aidukaite, J. (2009). Transformation of welfare systems in the Baltic States: Estonia, Latvia and Lithuania. In: Cerami, A. and Vanhuysse, P. (eds.). Post-communist Welfare Pathways: Theorizing Social Policy Transformations in CEE. Basingstoke: Palgrave Macmillan: 96-111.

Aidukaite, J. (2011). The "Baltic Welfare State" after 20 years of transition. In: Estonian Human Development Report Baltic Way(s) of Human Development: Twenty Years On. Tallinn: AS Eesti Ajalehed: 70-74.

Amato, P.R. (1996). Explaining the intergenerational transmission of divorce. Journal of Marriage and the Family 58(3): 628-640. doi:10.2307/353723.

Amato, P.R. and James, S. (2010). Divorce in Europe and the United States: Commonalities and differences across nations. Family Science 1(1): 2-13. doi:10.1080/19424620903381583.

Becker, G.S., Landes, E.M., and Michael, R.T. (1977). An economic analysis of marital instability. Journal of Political Economy 85: 1141-1187. doi:10.1086/260631.

Becker, G.S. (1981). A treatise on the family. Cambridge: Harvard University Press.

Bellani, D. and Esping-Andersen, G. (2011). Divorce in multiple equilibria: An application to Germany. Paper presented at the 9th Annual Meeting of the European Network for the Sociological and Demographic Study of Divorce, Milan, Italy, 27-30 October 2011.

Blossfeld, H.-P. and Müller, R. (2002). Union disruption in comparative perspective: the role of assortative partner choice and careers of couples. International Journal of Sociology 32: 3-35.

Bohle, D. and Gerskovits, B. (2007). Neoliberalism, embedded neoliberalism and neocorporatism: Towards transnational capitalism in Central-Eastern Europe. West European Politics 30(3): 443-466. doi:10.1080/01402380701276287.

Bukodi, E. and Róbert, P. (2003). Union disruption in Hungary. International Journal of Sociology 33(1): 64-94. 
Chan, T.W. and Halpin, B. (2002). Union dissolution in the United Kingdom. International Journal of Sociology 32(4): 76-93.

Cherlin, A.J. (1992). Marriage, divorce, remarriage. Cambridge, MA: Harvard University Press.

Cooke, L.P. (2004). The gendered division of labour and family outcomes in Germany. Journal of Marriage and Family 66(5): 1246-1259. doi:10.1111/j.00222445.2004.00090.x.

Cooke, L.P. (2006). Doing gender in context: household bargaining and the risk of divorce in Germany and the United States. American Journal of Sociology 112(2): 442-472. doi:10.1086/506417.

Cooke, L.P. and Gash, V. (2010). Wives' part-time employment and marital stability in Great Britain, West Germany and the United States. Sociology 44(6): 1091-1108. doi:10.1177/0038038510381605.

Cooke, L.P., Erola, J., Evertsson, M., Gahler, M., Harkonen, J., Hewitt, B., Jalovaara, M., Kan, M.-Y., Lyngstad, T.H., Mencarini, L., Mignot, J.-F., Mortelmans, D., Poortman, A.-R., Schmitt, C., and Trappe, H. (2013). Labor and love: wives' employment and divorce risk in its socio-political context. Social Politics 20(4): 482-509. doi:10.1093/sp/jxt016.

Council of Europe (2006). Recent demographic developments in Europe. Strasbourg: Council of Europe Publishing.

de Graaf, P.M. and Kalmijn, M. (2006). Change and stability in the social determinants of divorce: a comparison of marriage cohorts in the Netherlands. European Sociological Review 22(5): 561-572. doi:10.1093/esr/jcl010.

Eurostat (2014). Population with tertiary education attainment by sex and age.Luxemburg. http://epp.eurostat.ec.europa.eu/portal/page/portal/education/ data/database.

Frisco, M.L. and Williams, K. (2003). Perceived housework equity, marital happiness, and divorce in dual-earner households. Journal of Family Issues 24(1): 51-73. doi:10.1177/0192513X02238520.

Goode, W.J. (1962). Marital satisfaction and instability. A cross-cultural class analysis of divorce rates. International Social Science Journal XIV(3): 507-526.

Goode, W.J. (1993). World changes in divorce patterns. Yale: Yale University Press. 
Hakim, C. (2003). Models of the Family in Moderns Society. Ideals and Realities. Aldershot: Ashgate.

Hansen, H.-T. (2005). Unemployment and marital dissolution: a panel data study of Norway. European Sociological Review 21(2): 135-148. doi:10.1093/esr/jci009.

Härkönen, J. and Dronkers, J. (2006). Stability and change in the educational gradient of divorce. A comparison of seventeen countries. European Sociological Review 22(5): 501-517. doi:10.1093/esr/jcl011.

Härkönen, J. (2013). Divorce: Trends, Patterns, Causes, Consequences. In: Stockholm Research Reports in Demography 2013(7). Stockholm: Stockholm University: $1-39$.

Härkönen, J. (2014). Emerging trends in divorce research. In: Stockholm Research Reports in Demography 2014(7). Stockholm: Stockholm University: 1-22.

Hoem, J.M. (1997). Educational gradients in divorce risks in Sweden in recent decades. Population Studies 51(1): 19-27. doi:10.1080/0032472031000149696.

Inglehart, R. and Noris, P. (2003). Rising tide: gender equality and cultural change around the World. Cambridge: Cambridge University Press. doi:10.1017/CBO 9780511550362.

ITCD (Information Technology and Communications Department under the Ministry of the Interior of the Republic of Lithuania) (2014). Nuo nusikalstamu veiku nukentejusios moterys [Female victims from criminal offenses]. Vilnius: Ministry of the Interior of the Republic of Lithuania.

Jalovaara, M. (2001). Socio-economic status and divorce in first marriages in Finland 1991-93. Population Studies 55(2): 119-133. doi:10.1080/00324720127685.

Jalovaara, M. (2003). The joint effects of marriage partners' socioeconomic positions on the risk of divorce. Demography 40(1): 67-81. doi:10.1353/dem.2003.0004.

Juozeliūnienè, I. and Kanopienè, V. (1995). Women and Family in Lithuania. In: Lobodzinska, B. (ed.). Family, Women, and Employment in Central Eastern Europe. Westport: Greenwood Press: 155-165.

Kanopiené, V. (1998).Women in Economy. In: La Font, S. (ed.). Women in Transition. Voices from Lithuania. Albany: State University of New York Press: 68-80.

Lyngstad, T.H. and Jalovaara, M. (2010). A review of the antecedents of union dissolution. Demographic Research 23(10): 257-292. doi:10.4054/DemRes. 2010.23.10. 
Lauristin, M. (2011). Introduction. Human development during the period of transition: the challenges faced by the Baltic states. In: Estonian Human Development Report Baltic Way(s) of Human Development: Twenty Years On. Tallinn: AS Eesti Ajalehed: 10-12.

Liefbroer, A.C. and Dourleijn, E. (2006). Unmarried cohabitation and union stability: testing the role of diffusion using data from 16 European countries. Demography 43(2): 203-221. doi:10.1353/dem.2006.0018.

Matysiak, A., Styrc, M., and Vignoli, D. (2014). The educational gradient in marital disruption: A meta-analysis of European research findings. Population Studies 68(2): 197-215. doi:10.1080/00324728.2013.856459.

Monastiriotis, V. (2011). Regional growth dynamics in Central and Eastern Europe. In: LSE 'Europe in Question' Discussion Paper Series. London: London School of Economics and Political Science: 1-34.

Motiejūnaite, A. (2010). Female employment in Lithuania: Testing three popular explanations. Journal of Baltic Studies 41(2): 237-258. doi:10.1080/01629771 003731754.

Muszynska, M. (2008). Women's employment and union dissolution in a changing socio-economic context in Russia. Demographic Research 8(6): 181-204. doi:10.4054/DemRes.2008.18.6.

NIDI (Netherlands Interdisciplinary Demographic Institute) (2014). Generations and Gender Contextual Database [electronic resource]. The Hague: Netherlands Interdisciplinary Demographic Institute. www.ggp-i.org/contextualdatabase.html.

Norkus, Z. (2013). How many times capitalism was restored in Lithuania? On two occupations of Lithuania and their damage calculations. Sociologija. Mintis ir veiksmas 2(33): 91-133.

Oppenheimer, V. (1997). Women's employment and the gain to marriage: the specialization and trading model. Annual Review of Sociology 23(1): 431-453. doi:10.1146/annurev.soc.23.1.431.

Pampel, F.C. (2011). Cohort change, diffusion, and support for gender egalitarianism in cross-national perspective. Demographic Research 25(21): 667-694. doi:10.4054/DemRes.2011.25.21. 
Sigle-Rushton, W. (2010). Men's unpaid work and divorce: reassessing specialization and trade in British families. Feminist Economics 16(2): 1-26. doi:10.1080/13545700903448801.

Stankuniene, V., Jonkaryte, A., Mikulioniene, S., Mitrikas, A., and Maslauskaite, A. (2003). Šeimos revoliucija? Iššūkiai šeimos politikai. [Family revolution? Challenges for Family Policy].Vilnius: Institute for Social Research.

Stankuniene, V. and Maslauskaite, A. (2008). Family transformations in the postcommunist countries: Attitudes towards changes. In: Höhn, C., Avramov, D., and Kotowska, I.E. (eds.). People, Population Change and Policy Acceptance Study(Vol. 1). Berlin: Springer: 127-157. doi:10.1007/978-1-4020-6609-2_6.

Stankuniene, V., Maslauskaite, A., and Baublyte, M. (2013). Ar Lietuvos seimos bus gausesnes? [Are families to be larger in Lithuania?]. Vilnius: Lithuanian Social Research Centre.

Statistics Lithuania (2008). International migration of Lithuanian population. Vilnius: Statistics Lithuania.

Statistics Lithuania (2011). Demographic Yearbook 2010. Vilnius: Statistics Lithuania.

Statistics Lithuania (2012). Income and Living Conditions 2011. Vilnius: Statistics Lithuania.

Statistics Lithuania (2012a). Women and men in Lithuania 2011. Vilnius: Statistics Lithuania.

Stevenson, B. and Wolfers, J.(2007). Marriage and divorce: changes and their driving forces. Journal of Economic Perspectives 21(2): 27-52. doi:10.1257/jep.21.2.27.

Styrc, M. and Matysiak, A. (2012). Job and stable marriage? Effects of women's employment on marital stability in Poland. Paper presented at the European Divorce Research Conference, Helsinki, Finland, October 11-13, 2012.

Svarer, M. and Verner, M. (2006). Do children stabilize Danish marriages? Journal of Population Economics 21(2): 395-417. doi:10.1007/s00148-006-0084-9.

Westoff, C.F. and Higgins, J. (2009). Relationships between men's gander attitudes and fertility: Response to Puur et al.'s "Men's childbearing desires and views of the male role in Europe at the dawn of the 21st century". Demographic Research 21(3): 65-74. doi:10.4054/DemRes.2009.21.3. 
Zaidi, S. (2009). Main drivers of income inequality in Central European and Baltic Countries. The World Bank Europe and Central Asia Region, Policy Research Working Paper 4815. doi:10.1596/1813-9450-4815. 
Appendix 1: Poisson regression relative first divorce risks for all control variables, education, and economic activity status estimated for total population, large cities, other urban areas, and rural areas, adult females, 2001-2003

\begin{tabular}{|c|c|c|c|c|}
\hline Variables & Total population & Large cities & Other urban areas & Rural areas \\
\hline \multicolumn{5}{|c|}{ Duration of marriage (years) } \\
\hline$<1$ (ref.) & 1.00 & 1.00 & 1.00 & 1.00 \\
\hline $1-1.99$ & 1.25 & 1.47 & 1.16 & 0.92 \\
\hline $2-2.99$ & 1.81 & 2.20 & 1.73 & 1.12 \\
\hline $3-3.99$ & 1.96 & 2.38 & 1.86 & 1.29 \\
\hline $4-4.99$ & 2.02 & 2.55 & 1.72 & 1.40 \\
\hline $5-5.99$ & 1.82 & 2.26 & 1.70 & 1.10 \\
\hline $6-7.99$ & 1.99 & 2.60 & 1.72 & 1.19 \\
\hline $8-9.99$ & 1.86 & 2.46 & 1.59 & 1.08 \\
\hline $10-12.99$ & 1.75 & 2.32 & 1.50 & 0.97 \\
\hline$>13$ & 1.23 & 1.60 & 1.05 & 0.75 \\
\hline \multicolumn{5}{|l|}{ Marriage cohort } \\
\hline Before 1970 (ref.) & 1.00 & 1.00 & 1.00 & 1.00 \\
\hline $1970-1979$ & 2.39 & 2.50 & 2.34 & 2.12 \\
\hline 1980-1989 & 4.94 & 5.15 & 4.52 & 4.89 \\
\hline $1990-1994$ & 5.08 & 4.82 & 4.73 & 6.23 \\
\hline $1995-2001$ & 5.25 & 4.99 & 4.82 & 6.51 \\
\hline \multicolumn{5}{|c|}{ Age at marriage (years) } \\
\hline$<20$ (ref.) & 1.00 & 1.00 & 1.00 & 1.00 \\
\hline $20-24$ & 0.67 & 0.68 & 0.63 & 0.71 \\
\hline $25-29$ & 0.52 & 0.52 & 0.49 & 0.54 \\
\hline$>30$ & 0.45 & 0.45 & 0.45 & 0.45 \\
\hline \multicolumn{5}{|l|}{ Number of children } \\
\hline No children (ref.) & 1.00 & 1.00 & 1.00 & 1.00 \\
\hline 1 child & 0.98 & 0.78 & 1.49 & 1.08 \\
\hline 2 children & 0.62 & 0.47 & 1.00 & 0.70 \\
\hline 3 or more children & 0.61 & 0.42 & 1.03 & 0.75 \\
\hline Unknown & 1.30 & 1.13 & 1.90 & 1.07 \\
\hline
\end{tabular}




\section{Appendix 1: (Continued)}

\begin{tabular}{|c|c|c|c|c|}
\hline Variables & Total population & Large cities & Other urban areas & Rural areas \\
\hline \multicolumn{5}{|l|}{ Ethnicity } \\
\hline Lithuanian (ref.) & 1.00 & 1.00 & 1.00 & 1.00 \\
\hline Russian & 1.02 & 1.01 & 0.94 & 1.14 \\
\hline Polish & 0.69 & 0.69 & 0.62 & 0.69 \\
\hline Other & 0.85 & 0.90 & 0.77 & 0.72 \\
\hline Unknown & 6.59 & 6.36 & 7.03 & 2.76 \\
\hline \multicolumn{5}{|l|}{ Place of residence } \\
\hline Urban - large cities (ref.) & 1.00 & - & - & - \\
\hline Urban - other & 0.94 & - & - & - \\
\hline Rural & 0.67 & - & - & - \\
\hline \multicolumn{5}{|l|}{ Place of birth } \\
\hline Urban, Lithuania (ref.) & 1.00 & 1.00 & 1.00 & 1.00 \\
\hline Rural, Lithuania & 0.76 & 0.72 & 0.78 & 0.81 \\
\hline Other country & 1.01 & 0.91 & 1.19 & 1.13 \\
\hline Unknown & 2.30 & 2.42 & 2.96 & 0.63 \\
\hline \multicolumn{5}{|l|}{ Education } \\
\hline Higher (ref.) & 1.00 & 1.00 & 1.00 & 1.00 \\
\hline Secondary & 1.01 & 1.07 & 0.94 & 0.85 \\
\hline Lower than secondary & 1.23 & 1.55 & 1.01 & 0.93 \\
\hline \multicolumn{5}{|l|}{ Economic activity status } \\
\hline Active, employed (ref.) & 1.00 & 1.00 & 1.00 & 1.00 \\
\hline Active, unemployed & 1.02 & 0.88 & 1.04 & 1.39 \\
\hline Inactive, disabled & 0.98 & 0.86 & 1.01 & 1.25 \\
\hline Inactive, housewife & 0.74 & 0.63 & 0.84 & 0.82 \\
\hline Inactive, student & 0.99 & 0.95 & 1.02 & 1.15 \\
\hline Inactive, other & 0.88 & 0.82 & 0.92 & 1.08 \\
\hline Unknown & 4.36 & 4.07 & 2.56 & 4.85 \\
\hline
\end{tabular}

Notes: statistically significant relative risks are marked in bold $(\mathrm{p} \leq 0.05)$. 


\section{Appendix 2: Poisson regression relative first divorce risks for all control variables,} education, and economic activity status estimated for total population, large cities, other urban areas, and rural areas, adult males, 2001-2003

\begin{tabular}{|c|c|c|c|c|}
\hline Variables & Total population & Large cities & Other urban areas & Rural areas \\
\hline \multicolumn{5}{|c|}{ Duration of marriage (years) } \\
\hline$<1$ (ref.) & 1.00 & 1.00 & 1.00 & 1.00 \\
\hline $1-1.99$ & 1.12 & 1.43 & 0.86 & 1.07 \\
\hline $2-2.99$ & 1.41 & 1.92 & 1.10 & 1.14 \\
\hline $3-3.99$ & 1.62 & 2.20 & 1.26 & 1.31 \\
\hline $4-4.99$ & 1.56 & 2.05 & 1.24 & 1.31 \\
\hline $5-5.99$ & 1.35 & 1.87 & 1.00 & 1.11 \\
\hline $6-7.99$ & 1.47 & 2.06 & 1.06 & 1.21 \\
\hline $8-9.99$ & 1.33 & 2.00 & 0.90 & 1.00 \\
\hline $10-12.99$ & 1.12 & 1.71 & 0.75 & 0.83 \\
\hline$>13$ & 0.71 & 1.01 & 0.51 & 0.57 \\
\hline \multicolumn{5}{|l|}{ Marriage cohort } \\
\hline Before 1970 (ref.) & 1.00 & 1.00 & 1.00 & 1.00 \\
\hline $1970-1979$ & 2.26 & 2.23 & 2.04 & 2.45 \\
\hline 1980-1989 & 4.68 & 4.62 & 4.06 & 5.45 \\
\hline $1990-1994$ & 4.72 & 4.19 & 4.56 & 6.26 \\
\hline $1995-2001$ & 5.36 & 4.63 & 5.08 & 7.79 \\
\hline \multicolumn{5}{|l|}{ Age at marriage (years) } \\
\hline$<20$ (ref.) & 1.00 & 1.00 & 1.00 & 1.00 \\
\hline $20-24$ & 0.69 & 0.71 & 0.62 & 0.75 \\
\hline $25-29$ & 0.51 & 0.55 & 0.45 & 0.52 \\
\hline$>30$ & 0.49 & 0.55 & 0.41 & 0.46 \\
\hline \multicolumn{5}{|l|}{ Ethnicity } \\
\hline Lithuanian (ref.) & 1.00 & 1.00 & 1.00 & 1.00 \\
\hline Russian & 1.02 & 0.96 & 1.16 & 1.06 \\
\hline Polish & 0.68 & 0.67 & 0.66 & 0.66 \\
\hline Other & 0.83 & 0.80 & 0.87 & 0.87 \\
\hline Unknown & 10.05 & 11.12 & 12.18 & 3.25 \\
\hline \multicolumn{5}{|l|}{ Place of residence } \\
\hline Urban - large cities (ref.) & 1.00 & - & - & - \\
\hline Urban - other & 0.78 & - & - & - \\
\hline Rural & 0.54 & - & - & - \\
\hline
\end{tabular}




\section{Appendix 2: (Continued)}

\begin{tabular}{|c|c|c|c|c|}
\hline Variables & Total population & Large cities & Other urban areas & Rural areas \\
\hline \multicolumn{5}{|l|}{ Place of birth } \\
\hline Urban, Lithuania (ref.) & 1.00 & 1.00 & 1.00 & 1.00 \\
\hline Rural, Lithuania & 0.77 & 0.72 & 0.86 & 0.76 \\
\hline Other country & 1.03 & 0.94 & 1.14 & 1.06 \\
\hline Unknown & 3.53 & 3.70 & 5.49 & 1.36 \\
\hline \multicolumn{5}{|l|}{ Education } \\
\hline Higher (ref.) & 1.00 & 1.00 & 1.00 & 1.00 \\
\hline Secondary & 1.04 & 1.25 & 0.74 & 0.75 \\
\hline Lower than secondary & 1.27 & 1.76 & 0.82 & 0.81 \\
\hline \multicolumn{5}{|l|}{ Economic activity status } \\
\hline Active, employed (ref.) & 1.00 & 1.00 & 1.00 & 1.00 \\
\hline Active, unemployed & 1.43 & 1.25 & 1.54 & 1.70 \\
\hline Inactive, disabled & 1.28 & 1.15 & 1.33 & 1.57 \\
\hline Inactive, househusband & 1.09 & 1.08 & 1.19 & 1.16 \\
\hline Inactive, student & 1.17 & 1.18 & 0.93 & 1.85 \\
\hline Inactive, other & 1.42 & 1.16 & 1.48 & 1.90 \\
\hline Unknown & 4.60 & 3.73 & 4.22 & 7.99 \\
\hline
\end{tabular}

Notes: a) statistically significant relative risks are marked in bold ( $\leq \leq 0.05)$; b) outcomes from models including all variables. 


\section{Appendix 3: Main and interaction effects of sex and education on first divorce risk, Lithuania, adult females and males, 2001-2003}

\begin{tabular}{lc}
\hline Variables & First divorce rate ratios \\
\hline Sex (Main effect) & \\
\hline Male & 1.00 \\
Female & 1.08 \\
\hline Education (Main effect) & \\
\hline Higher & 1.00 \\
Secondary & 1.06 \\
Lower than secondary & 1.33 \\
\hline Sex and Education (Interaction effects) & \\
\hline Female, secondary education & 0.93 \\
Female, lower than secondary education & 0.88 \\
\hline LR test, Chi-square (df) & 13.07 (2) \\
& Prob >chi2 = 0.002 \\
\hline
\end{tabular}

Notes: a) statistically significant relative risks are marked in bold ( $p \leq 0.05)$; $b$ ) in addition to variables presented in this table, control variables include all remaining variables (including economic activity status). LR test compares the goodness of fit of the current model with interaction effects to the model without interaction effects (but controlling for all variables including education and economic activity status); c) interaction effects show proportional differences between females and males (reference) in effects of education on first divorce risk. These effects exist net of the main effects of sex and education. 


\section{Appendix 4: Main and interaction effects of sex and economic activity status on first divorce risk, Lithuania, adult females and males, 2001-2003}

\begin{tabular}{|c|c|}
\hline Variables & First divorce rate ratios \\
\hline \multicolumn{2}{|l|}{ Sex (Main effect) } \\
\hline Male & 1.00 \\
\hline Female & 1.11 \\
\hline \multicolumn{2}{|l|}{ Economic activity status (Main effect) } \\
\hline Active, employed & 1.00 \\
\hline Active, unemployed & 1.42 \\
\hline Inactive, disabled & 1.26 \\
\hline Inactive, housewife & 1.07 \\
\hline Inactive, student & 1.20 \\
\hline Inactive, other & 1.42 \\
\hline Unknown & 4.88 \\
\hline \multicolumn{2}{|c|}{ Sex and Economic activity status (Interaction effects) } \\
\hline Female, active, unemployed & 0.72 \\
\hline Female, inactive, disabled & 0.81 \\
\hline Female, inactive, housewife / househusband & 0.64 \\
\hline Female, inactive, student & 0.82 \\
\hline Female, inactive, other & 0.59 \\
\hline Female, unknown & 0.87 \\
\hline \multirow[t]{2}{*}{ LR test, Chi-square (df) } & $231.85(6)$ \\
\hline & Prob $>$ chi2 $=0.000$ \\
\hline
\end{tabular}

Notes: a) statistically significant relative risks are marked in bold ( $p \leq 0.05)$; b) in addition to variables presented in this table, control variables include all remaining variables (including education). LR test compares the goodness of fit of the current model with interaction effects to the model without interaction effects (but controlling for all variables including education and economic activity status); c) interaction effects show proportional differences between females and males (reference) in effects of economic activity status on first divorce risk. These effects exist net of the main effects of sex and economic activity status. 


\section{Appendix 5: Main and interaction effects of place of residence and education on first divorce risk, Lithuania, adult females and males, 2001-2003}

\begin{tabular}{|c|c|c|}
\hline Variables & Females & Males \\
\hline \multicolumn{3}{|l|}{ Place of residence (Main effect) } \\
\hline Urban - large cities & 1.00 & 1.00 \\
\hline Urban - other & 1.03 & 1.18 \\
\hline Rural & 0.75 & 0.78 \\
\hline \multicolumn{3}{|l|}{ Education (Main effect) } \\
\hline Higher & 1.00 & 1.00 \\
\hline Secondary & 1.04 & 1.21 \\
\hline Lower than secondary & 1.45 & 1.58 \\
\hline \multicolumn{3}{|l|}{ Place of residence and Education (Interaction effects) } \\
\hline Secondary education, urban - other cities & 0.92 & 0.62 \\
\hline Secondary education, rural & 0.89 & 0.67 \\
\hline Lower than secondary education, urban - other cities & 0.73 & 0.57 \\
\hline \multirow[t]{2}{*}{ Lower than secondary education, rural } & 0.77 & 0.60 \\
\hline & $29.28(4)$ & $126.08(4)$ \\
\hline \multirow[t]{2}{*}{ LR test, Chi-square (df) } & Prob $>$ chi2 $=$ & Prob $>$ chi2 $=0.000$ \\
\hline & 0.000 & \\
\hline
\end{tabular}

Notes: a) statistically significant relative risks are marked in bold ( $p \leq 0.05)$; b) in addition to variables presented in this table, control variables include all remaining variables. LR test compares the goodness of fit of the current model with interaction effects to the model without interaction effects (but controlling for all variables); c) interaction effects show proportional differences between other urban, rural and large city males (reference) in effects of education status on first divorce risk. These effects exist net of the main effects of place of residence and education. 


\section{Appendix 6: Main and interaction effects of place of residence and economic activity status on first divorce risk, Lithuania, adult females and males, 2001-2003}

\begin{tabular}{|c|c|c|}
\hline Variables & Females & Males \\
\hline \multicolumn{3}{|l|}{ Place of residence (Main effect) } \\
\hline Urban - large cities & 1.00 & 1.00 \\
\hline Urban - other & 0.91 & 0.76 \\
\hline Rural & 0.60 & 0.49 \\
\hline \multicolumn{3}{|l|}{ Economic activity status (Main effect) } \\
\hline Active, employed & 1.00 & 1.00 \\
\hline Active, unemployed & 0.90 & 1.31 \\
\hline Inactive, disabled & 0.90 & 1.26 \\
\hline Inactive, housewife / househusband & 0.62 & 1.14 \\
\hline Inactive, student & 0.93 & 1.06 \\
\hline Inactive, other & 0.80 & 1.20 \\
\hline Unknown & 4.83 & 4.21 \\
\hline \multicolumn{3}{|c|}{ Place of residence and Economic activity status (Interaction effects) } \\
\hline Active, unemployed and urban - other & 1.14 & 1.11 \\
\hline Active, unemployed and rural & 1.51 & 1.26 \\
\hline Inactive, disabled and urban - other & 1.11 & 0.99 \\
\hline Inactive, disabled and rural & 1.26 & 1.09 \\
\hline Inactive, housewife / househusband and urban - other & 1.35 & 1.00 \\
\hline Inactive, housewife / househusband and rural & 1.35 & 0.98 \\
\hline Inactive, student and urban - other & 1.10 & 0.95 \\
\hline Inactive, student and rural & 1.35 & 2.17 \\
\hline Inactive, other and urban - other & 1.15 & 1.20 \\
\hline Inactive, other and rural & 1.34 & 1.55 \\
\hline Unknown, urban - other & 0.52 & 0.98 \\
\hline \multirow[t]{2}{*}{ Unknown and rural } & 0.86 & 1.55 \\
\hline & $39.25(12)$ & $57.81(12)$ \\
\hline \multirow[t]{2}{*}{ LR test, Chi-square (df) } & Prob > chi2 & Prob $>$ chi2 $=$ \\
\hline & $=0.000$ & 0.000 \\
\hline
\end{tabular}

Notes: a) statistically significant relative risks are marked in bold ( $p \leq 0.05)$; b) in addition to variables presented in this table, control variables include all remaining variables. LR test compares the goodness of fit of the current model with interaction effects to the model without interaction effects (but also controlling for all variables); c) interaction effects show proportional differences between other urban and rural males and large city males (reference) in effects of economic activity status on first divorce risk. These effects exist net of the main effects of place of residence and education. 


\section{Appendix 7: Main and interaction effects of education and economic activity status on first divorce risk, Lithuania, adult females, 2001-2003}

\begin{tabular}{|c|c|c|c|c|}
\hline Education / economic activity status category & Total population & Large cities & $\begin{array}{c}\text { Other urban } \\
\text { areas }\end{array}$ & Rural areas \\
\hline \multicolumn{5}{|l|}{ Education } \\
\hline Higher & 1.00 & 1.00 & 1.00 & 1.00 \\
\hline Secondary & 0.99 & 1.06 & 0.93 & 0.87 \\
\hline Lower than secondary & 1.23 & 1.76 & 0.98 & 0.87 \\
\hline \multicolumn{5}{|l|}{ Economic activity status } \\
\hline Active, employed & 1.00 & 1.00 & 1.00 & 1.00 \\
\hline Active, unemployed & 1.10 & 1.04 & 1.10 & 1.84 \\
\hline Inactive, disabled & 1.05 & 1.05 & 1.05 & 0.99 \\
\hline Inactive, housewife & 0.57 & 0.55 & 0.52 & 0.87 \\
\hline Inactive, student & 0.77 & 0.84 & 0.94 & 0.35 \\
\hline Inactive, other & 0.68 & 0.65 & 0.71 & 1.41 \\
\hline Unknown & 1.64 & 1.92 & 1.60 & - \\
\hline \multicolumn{5}{|c|}{ Education and Economic activity status (Interaction effects) } \\
\hline Secondary and active, unemployed & 0.95 & 0.87 & 0.95 & 0.74 \\
\hline Lower than secondary and active, unemployed & 0.85 & 0.55 & 0.90 & 0.81 \\
\hline Secondary and inactive, disabled & 0.99 & 0.87 & 0.97 & 1.34 \\
\hline Lower than secondary and inactive, disabled & 0.77 & 0.48 & 0.93 & 1.20 \\
\hline Secondary and inactive, housewife & 1.30 & 1.19 & 1.62 & 0.89 \\
\hline Lower than secondary and inactive, housewife & 1.38 & 1.08 & 1.81 & 1.09 \\
\hline Secondary and inactive, student & 1.29 & 1.20 & 0.98 & 3.25 \\
\hline Lower than secondary and inactive, student & 1.51 & 0.97 & 1.44 & 4.33 \\
\hline Secondary and inactive, other & 1.39 & 1.38 & 1.39 & 0.77 \\
\hline Lower than secondary and inactive, other & 1.21 & 1.09 & 1.15 & 0.76 \\
\hline Secondary and unknown & 2.83 & 2.90 & 1.30 & - \\
\hline Lower than secondary and unknown & 2.71 & 1.60 & 1.99 & - \\
\hline LR test, Chi-square (df) & $\begin{array}{c}35.38(\mathbf{1 2}) \\
\text { Prob }>\text { chi2 }=0.000\end{array}$ & $\begin{array}{c}42.82(12) \\
\text { Prob }>\text { chi2 }=0.000\end{array}$ & $\begin{array}{c}12.12(12) \\
\text { Prob }>\text { chi2 }=0.436\end{array}$ & $\begin{array}{c}20.21(12) \\
\text { Prob }>\text { chi2 }=0.063\end{array}$ \\
\hline
\end{tabular}

Notes: a) statistically significant relative risks are marked in bold ( $p \leq 0.05)$; b) in addition to variables presented in this table, control variables include all remaining variables. LR test compares the goodness of fit of the current model with interaction effects to the model without interaction effects (but also controlling for all variables); c) interaction effects show proportional differences between other males with secondary and lower secondary education and males with higher education (reference) in effects of economic activity status on first divorce risk. These effects exist net of the main effects of place of education economic activity status. 


\section{Appendix 8: Main and interaction effects of education and economic activity status on first divorce risk, Lithuania, adult males, 2001-2003}

\begin{tabular}{|c|c|c|c|c|}
\hline Education / economic activity status category & $\begin{array}{c}\text { Total } \\
\text { population }\end{array}$ & Large cities & $\begin{array}{c}\text { Other urban } \\
\text { areas }\end{array}$ & Rural areas \\
\hline \multicolumn{5}{|l|}{ Education } \\
\hline Higher & 1.00 & 1.00 & 1.00 & 1.00 \\
\hline Secondary & 1.03 & 1.27 & 0.71 & 0.74 \\
\hline Lower than secondary & 1.32 & 2.02 & 0.80 & 0.80 \\
\hline \multicolumn{5}{|l|}{ Economic activity status } \\
\hline Active, employed & 1.00 & 1.00 & 1.00 & 1.00 \\
\hline Active, unemployed & 1.46 & 1.58 & 1.22 & 1.40 \\
\hline Inactive, disabled & 1.74 & 1.96 & 0.62 & 2.86 \\
\hline Inactive, househusband & 1.42 & 1.23 & 0.35 & 2.51 \\
\hline Inactive, student & 0.88 & 1.15 & 0.00 & 0.79 \\
\hline Inactive, other & 1.32 & 1.41 & 1.18 & 1.09 \\
\hline Unknown & 2.57 & 3.37 & 0.00 & 3.88 \\
\hline \multicolumn{5}{|c|}{ Education and Economic activity status (Interaction effects) } \\
\hline Secondary and active, unemployed & 1.00 & 0.82 & 1.28 & 1.22 \\
\hline Lower than secondary and active, unemployed & 0.92 & 0.60 & 1.26 & 1.24 \\
\hline Secondary and inactive, disabled & 0.81 & 0.68 & 2.36 & 0.56 \\
\hline Lower than secondary and inactive, disabled & 0.50 & 0.21 & 1.92 & 0.47 \\
\hline Secondary and inactive, househusband & 0.74 & 0.89 & 3.21 & 0.43 \\
\hline Lower than secondary and inactive, househusband & 0.79 & 0.77 & 4.63 & 0.49 \\
\hline Secondary and inactive, student & 1.47 & 1.10 & - & 2.80 \\
\hline Lower than secondary and inactive, student & 1.10 & 0.52 & - & 2.12 \\
\hline Secondary and inactive, other & 1.10 & 0.82 & 1.35 & 1.78 \\
\hline Lower than secondary and inactive, other & 1.01 & 0.67 & 1.02 & 1.74 \\
\hline Secondary and unknown & 1.84 & 1.21 & - & 2.08 \\
\hline Lower than secondary and unknown & 1.75 & 0.93 & - & 2.09 \\
\hline \multirow[t]{2}{*}{ LR test, Chi-square (df) } & $28.86(12)$ & $53.90(12)$ & $22.89(12)$ & $11.75(12)$ \\
\hline & Prob $>$ chi $2=0.004$ & Prob $>$ chi2 $=0.000$ & Prob $>$ chi $2=0.029$ & Prob $>$ chi2 $=0.466$ \\
\hline
\end{tabular}

Notes: a) statistically significant relative risks are marked in bold ( $p \leq 0.05)$; b) in addition to variables presented in this table, control variables include all remaining variables. LR test compares the goodness of fit of the current model with interaction effects to the model without interaction effects (but also controlling for all variables); c) interaction effects show proportional differences between other males with secondary and lower secondary education and males with higher education (reference) in effects of economic activity status on first divorce risk. These effects exist net of the main effects of place of education and economic activity status. 
Maslauskaite et al.: Socio-economic determinants of divorce in Lithuania 